\title{
Effects of Temperature on the Long-Term Behaviour of Waste Degradation, Emissions and Post-Closure Management Based on Landfill Simulators
}

\author{
Y. Wang*, M. Pelkonen and J. Kaila \\ School of Engineering, Aalto University, Tietotie 1 E, P.O. Box 5200, FIN-02105 Espoo, Finland
}

\begin{abstract}
A demonstration pilot with seven anaerobic landfill simulators (LSRs) was used to study the impact of temperature in the range of $20-46{ }^{\circ} \mathrm{C}$ on long-term landfill emissions, characteristics and tendencies, because of an evident lack of knowledge in this area. The pilot ran more than 1400 days. Higher temperatures accelerated the waste degradation and gas generation, but also resulted in higher leachate $\mathrm{COD}$ and $\mathrm{NH}_{4}-\mathrm{N}$ concentrations, which will prolong the aftercare period in order to meet the effluent discharge limits. Gas generation showed the highest temperature sensitivity, 1.6- $2.8 \%{ }^{\circ} \mathrm{C}^{-1}$, whereas $\mathrm{COD}, \mathrm{NH}_{4}-\mathrm{N}$ and chloride emissions were on $0.8-1.5 \%{ }^{\circ} \mathrm{C}^{-1}$ level. The temperature coefficient of gas generation differs considerably from the scarce values given in landfill simulation studies, but is in accordance with hydrolysis solubilisation related behaviour and gives thus more detailed information of landfill behaviour at different temperatures. The simulator results were applied in European conditions in a typical big landfill containing mainly organic matter, giving the length of aftercare over 200 years to achieve effluent discharge limits. Within the same aftercare period (around 200 years), mesophilic conditions compromised high gas production and near lowest leachate concentrations. The in situ landfill leachate pre-treatment process and a specific leachate management system are essential in order to achieve cost-effective and shorter landfill aftercare. The results give new information for evaluation and modelling of landfill control strategies in long-term in various environmental conditions.
\end{abstract}

Keywords: Municipal waste management, landfill simulators, long-term emissions, temperature coefficient, landfill leachate management.

\section{INTRODUCTION}

Landfilling is the most widely used and economical method for ultimately disposing of municipal solid waste. In the past thirty years, landfill operations have undergone a dramatic change, evolving from a storage/containment or "dry cell" concept to a process-based approach, in other words, a bioreactor landfill $[1,2]$. The tendency of waste management strategy is to utilise most of the reusable and recyclable waste and minimise the waste deposited in the landfill. The tendency started in the 1990s and has been accelerated by government decisions and regulations. For example, the Finnish landfill regulation requires that at least $50 \%$ of the recyclable part of the waste must be separated before landfilling, and the tax on the waste deposited in the landfill is 30 euroton $^{-1}$ more than the bio-waste collected and treated separately (Ministry of the Environment, 1996).

Landfills may release environmentally harmful emissions over hundreds of years [3]. Waste in landfills converts to organic and inorganic compounds in the gaseous/liquid states by undergoing various chemical and biological transformations, leading to the formation of landfill gas (LFG) and landfill leachate. These processes are generally divided into four phases. In hydrolysis particulate material is converted to soluble compounds, which are degraded to simpler acids, alcohols and $\mathrm{CO}_{2}$ (acidogenesis). Then

*Address correspondence to this author at the School of Engineering, Aalto University, Tietotie 1 E P.O.Box 5200, FIN-02105 Espoo, Finland;

Tel: +358 40 8297656; Fax: +35894513856;

E-mails: yu.wang@aalto.fi,yu.wang@tkk.fi degradation continues to acetate and hydrogen formation (acetogenesis) and finally methane and $\mathrm{CO}_{2}$ formation (methanogenesis). The landfill temperature, moisture content/additive water amount, water characteristics (i.e., precipitation rainfall or other water entering landfills), available oxygen and waste characteristics are among the many factors contributing to gas and leachate generation at landfill sites and subsequently determine the characteristics of LFG and landfill leachate [4]. Furthermore, the different forms of degradation are not definitive, since dynamic variations in the environmental conditions result in changes in their distribution and rates within the landfill $[5,6]$.

The management of landfill emissions, for both the long term and after closure, is an important and resource-intensive task. Landfills are usually operated for decades. The potential environmental risks should be understood completely in order to achieve the sustainability of landfill operational strategies. Among other factors, the landfill temperature plays a key role in determining the long-term potential of landfill emission. The actual landfill temperature may vary widely within one landfill. In Nordic conditions, winter temperatures of $5-35^{\circ} \mathrm{C}$ and summer temperatures of 10 - $45{ }^{\circ} \mathrm{C}$ have been measured, which cover the psychrophilic $\left(\leq 20^{\circ} \mathrm{C}\right)$, mesophilic $\left(\leq 40^{\circ} \mathrm{C}\right)$ and lower thermophilic ranges $\left(\leq 50{ }^{\circ} \mathrm{C}\right)$. The landfill temperature is affected by the size and height of the landfill, climatic conditions and landfilling operations, which determine the circumstances in which microbial decomposition occurs. Understanding the impact of temperature on landfill emissions, especially landfill leachate, is significant for the improvement of long-term landfill management strategies, in 
order to minimise landfill emissions, accelerate waste stabilisation and shorten the landfill aftercare period. The leachate quality varies significantly in the transition from acidogenesis to methanogenesis. The biodegradation rate increases with temperature, but within certain limits. Rees [7] identified that the necessity of maintaining temperatures of about $45^{\circ} \mathrm{C}$ in a conventional anaerobic landfill. Similarly, Hartz et al. [8] investigated the seven different temperatures ranged from $21^{\circ} \mathrm{C}$ to $48^{\circ} \mathrm{C}$ and found that $41{ }^{\circ} \mathrm{C}$ was the optimum temperature for short-term methane production. Mata-Alvares and Martina-Verdure [9] reported that the optimum temperature was $34{ }^{\circ} \mathrm{C}$ to $38{ }^{\circ} \mathrm{C}$, independent of leachate recirculation. Blakey et al. [10] reported that temperature may be an important factor affecting the methane content of LFG. The operation of landfills under optimum temperatures will result in faster rates of gas production and refuse stabilisation. In addition, the transition from the acetogenic to methanogenic phase can be shortened when the landfill is operated in warmer climates. Robinson [11] summarised that the transition period from the acetogenic to the methanogenic phase of the landfills in temperate countries was two or three times that of landfills in warmer climates. High methane production and a rapid transition from acidogenesis to methanogenesis can reduce the content of VFAs (volatile fatty acid) in leachate, rendering low BOD (biochemical oxygen demand) and $\mathrm{BOD} / \mathrm{COD}$ (chemical oxygen demand) ratios.

According to the EU Landfill Directive, the aftercare criteria of a closed landfill include waste/land stabilisation, LFG production, leachate/groundwater control and landfill utilisation; and landfill aftercare ends only when no activities are required to ensure that no adverse effects on the environment will result from the closed landfill [12]. Cost is also a critical issue to consider since the closure and aftercare of the landfill operation are the obligation of the owner/operator of closed landfills. It was estimated that the aftercare cost of sanitary landfills is around 13 eurom $^{-3}$ based on the assumption of at least a 30 -year aftercare period [13, 14].

In order to address these questions, operation and optimisation of landfill simulators play an increasing role in the selection of an environmentally sound, economically feasible and socially acceptable landfill management strategy. Landfill simulators (LSRs) are primarily applied to obtain a more realistic picture of waste degradation and leaching and optimise waste stabilisation in order to shorten the aftercare time. By significantly higher water application in the anaerobic or aerobic LSR tests, long-term development of leachate quality and gas generation can be rather quickly simulated [15-18] or more selectively the impact of temperature [19].

Some experimental studies using LSRs were performed to determine the influence of such stabilisation enhancement technologies as the shredding of waste, addition of nutrients, sludge addition and waste compaction on the performance of biodegradation in bioreactor landfills (e.g., [1]).

Recently efforts have been made to develop mathematical models and apply them to experiments performed with LSRs [20-22]. According to Valencia [23] the main limitation of models is the incorporation of temperature impacts. In most of the studies referred to, a constant temperature was applied and the impact of different temperature ranges on long-term emissions of landfilled waste has not been addressed before, indicating the need for additional studies.

This study is a long-term LSR demonstration project, which ran 1400 days from the end of 2004. The goal was to evaluate the impact of temperature (range $20-46{ }^{\circ} \mathrm{C}$ ) on degradation and leaching phenomena based on the different simulated annual liquid to solid ratios (L/S ratio) applied. In a previous paper, the behaviour of the starting phase up to moderate L/S ratios was studied [18]. This paper focuses on higher $\mathrm{L} / \mathrm{S}$ ratios, and the results provide relevant long-term emission (landfill leachate) and degradation (LSR) data for cost-effective leachate controlling purposes in landfills operating at the temperature range usually found.

\section{MATERIALS AND METHODS}

This study is continuation of a long-term LSR demonstration experiment and for a detailed description of experiments the previous publication is referred [18]. Shortly, waste was sampled from a large landfill near Helsinki at different depths and combined to form a representative average composition with age of around 3 years. Approximately $85 \mathrm{~kg}$ of this originally municipal solid waste (MSW) containing mostly organic matter was filled to each reactor. A schematic diagram of the LSRs is shown in Fig. (1) and the values of operation parameters are listed in Table 1.

\section{RESULTS AND DISCUSSION}

Among the seven reactors, which ran at different temperatures and with various liquid to solid (L/S) ratios, two pairs of parallel reactors were operated under the same conditions, which showed a similar behaviour with only minor differences. It indicates that the aim of carefully filling and operating the LSRs was accomplished and the material in each reactor was very similar.

As the impact of the applied annual L/S ratio was ignored, the time to achieve an $\mathrm{L} / \mathrm{S}$ ratio of 1 was estimated to correspond to an actual landfill period of 47 years, based on assumptions shown in Table 1 . The unit L/S ratio can easily be adjusted according to different local conditions (waste height, precipitation), if necessary.

The EU member states formulate the self-determining leachate treatment and discharge limits. In Finland, this standard is linked to the landfill environmental permit and varies according to the size of the landfill. The decision of the leachate discharge limits strongly influences the leachate management and landfill aftercare strategy. It is assumed that the target values for leachate discharge to end the aftercare period are $200 \mathrm{mg} \mathrm{CODL}^{-1}, 30 \mathrm{mg} \mathrm{BODL}^{-1}$, and $70 \mathrm{mg}$ $\mathrm{NH}_{4}-\mathrm{NL}^{-1}$, respectively. For the important inorganic component parameter, chlorides, it is assumed to be 100 $\mathrm{mgL}^{-1}$. For indirect leachate discharge COD limit is assumed as $1500 \mathrm{mgL}^{-1}$. Given limits are mainly based on European conditions [15]. For LFG emission, the target value is assumed to be $1 \mathrm{Lkg}^{-1}$ waste (dry)year ${ }^{-1}$ for big landfills. For smaller landfills, the emission target value for aftercare could be no more than $1.5 \mathrm{Lkg}^{-1}$ waste (dry)year ${ }^{-1}$ [13]. 


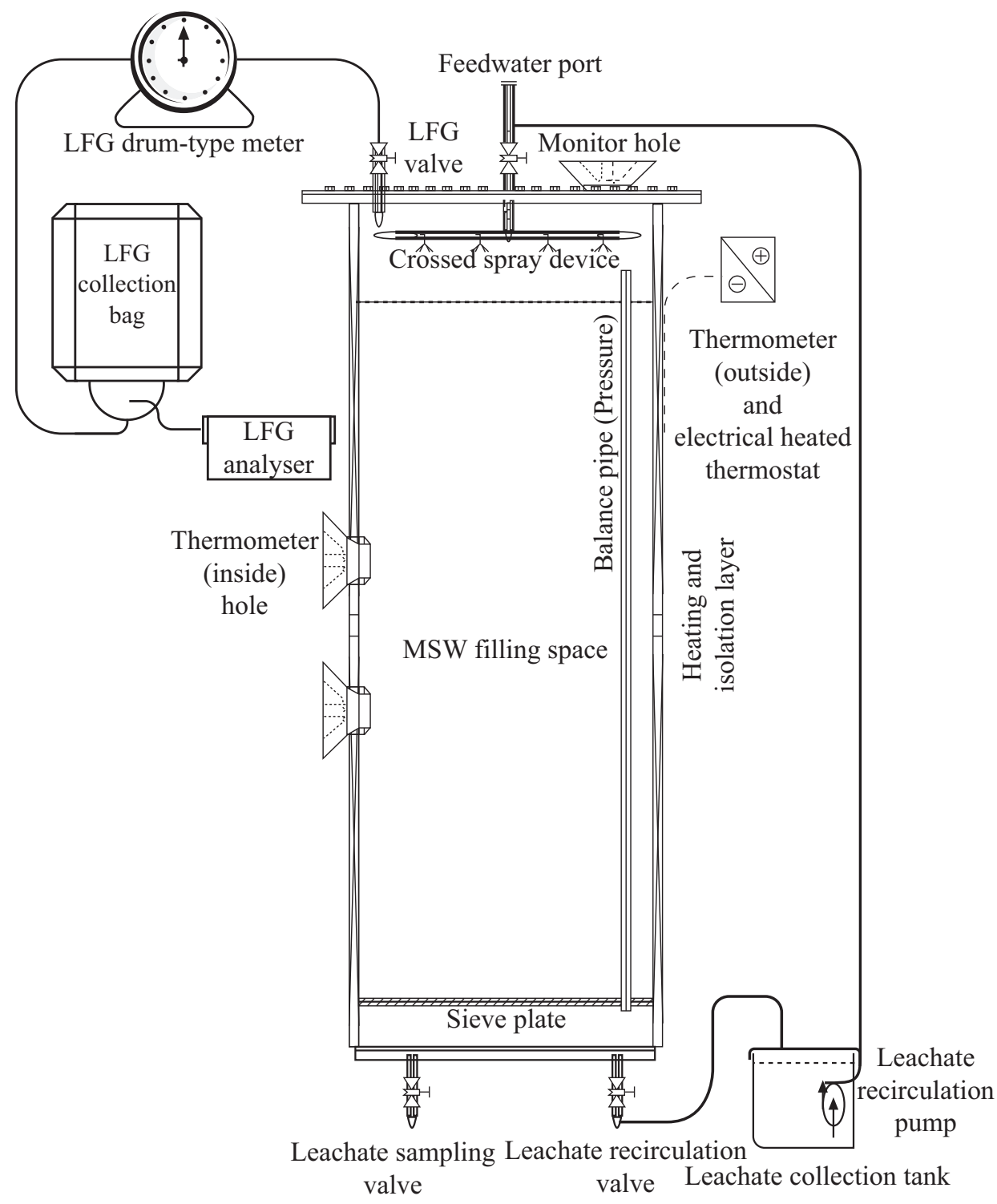

Fig. (1). Schematic diagram of LSRs

\section{Conductivity and Chlorides}

The variation of leachate conductivity is illustrated in Fig. (2a) as time series. The lowest release of salts can be found at the psychrophilic LSR, especially with a L/S ratio lower than 2. After this, the conductivity values reached practically the same level in reactors at different temperatures (Fig. 2b), meaning the impact of temperature on biological activities decreased. However, the difference of the leachate conductivity at different temperatures stayed at a stable, low level (standard deviation: $0.2 \mathrm{mScm}^{-1}$ ) but did not disappear.

The tendency of chlorides was synchronous with that of conductivity (Fig. 2c). When $\mathrm{L} / \mathrm{S}=1.30$, the chloride concentration decreased to $1170 \mathrm{mgL}^{-1}$, which was $87 \%$ and $91 \%$ of the mesophilic and thermophilic values, respectively. When $\mathrm{L} / \mathrm{S}=4.15$, the psychrophilic LSRs' leachate was 200 $\mathrm{mg} \mathrm{Cl} \mathrm{L}^{-1}$, which is still much higher than the target value. But the difference (standard deviation) among the different temperatures decreased to $34 \mathrm{mgL}^{-1}$, compared with 104
$\mathrm{mgL}^{-1}$ when $\mathrm{L} / \mathrm{S}=1.30$. Similarly with conductivity, the higher temperature activated the waste degradation and chloride emission, but this phenomenon weakened with an L/S ratio above 2 (Fig. 2d).

\section{COD}

The COD variations in the leachate are shown in Fig. $(3 \mathbf{a}, \mathbf{b})$. As a whole, owing to the rapid hydrolysis of the organics of MSW, the COD concentrations increased to $21000 \mathrm{mgL}^{-1}$ from an initial $15000 \mathrm{mgL}^{-1}$ with an $\mathrm{L} / \mathrm{S}$ ratio lower than 0.26 . When $\mathrm{L} / \mathrm{S}=1.3$, the $\mathrm{COD}$ concentration decreased at the lowest temperature to $1430 \mathrm{mgL}^{-1}$, which was $86 \%$ and $73 \%$ of the mesophilic and thermophilic values, respectively. These COD concentration levels are still much higher than the limit of leachate direct or even indirect discharge. The psychrophilic LSRs leachate reached the indirect discharge level of below $1500 \mathrm{mgL}^{-1}$ when $\mathrm{L} / \mathrm{S}=1.1$. The mesophilic LSRs then achieved it when $\mathrm{L} / \mathrm{S}=1.3$ and the thermophilic LSRs with an $\mathrm{L} / \mathrm{S}$ ratio of around 1.5. When $\mathrm{L} / \mathrm{S}=4.15$, the psychrophilic LSRs 
Table 1. Operational Parameters of LSRs

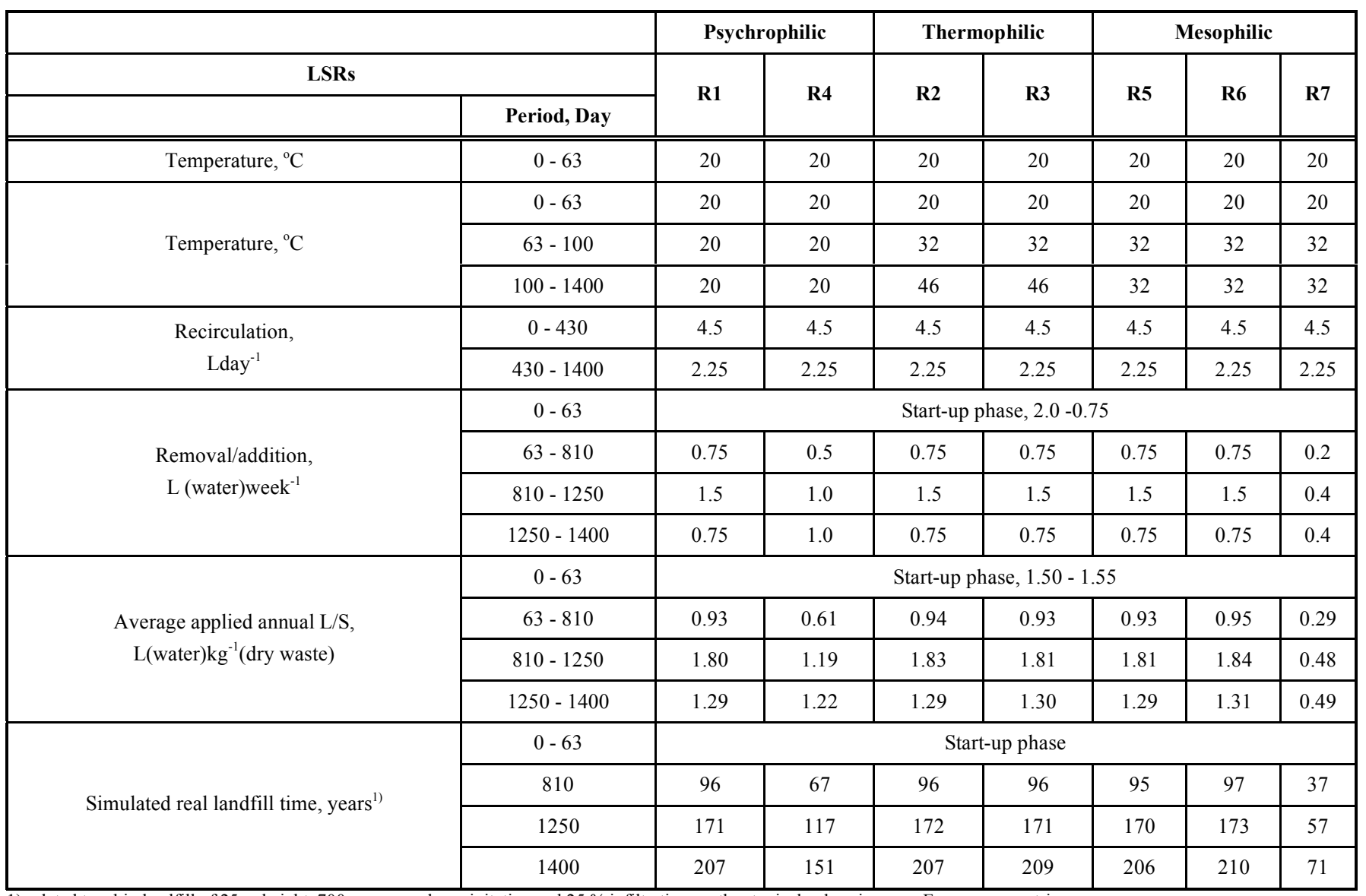

1) related to a big landfill of $25 \mathrm{~m}$ height, $700 \mathrm{~mm}$ annual precipitation and $25 \%$ infiltration - rather typical values in many European countries.

leachate COD concentration reached a direct discharge level below $200 \mathrm{mgL}^{-1}$, which was $81 \%$ of the mesophilic LSRs $\left(246 \mathrm{mgL}^{-1}\right)$ and $60 \%$ of the thermophilic LSRs $\left(330 \mathrm{mgL}^{-1}\right)$. Although the effect of temperatures (Fig. 3b) was decreasing, the COD concentration of the thermophilic LSR was still far from the target value.

The psychrophilic LSRs leachate met the target value for BOD emission when $\mathrm{L} / \mathrm{S}=1.7$. The mesophilic LSRs then achieved it when $\mathrm{L} / \mathrm{S}=2.3$ and the thermophilic LSRs when $\mathrm{L} / \mathrm{S}=2.8$. Therefore, BOD showed a better potential to achieve the target values, which is in accordance with the results found in mesophilic simulators [15].

\section{Ammonium Nitrogen $\left(\mathrm{NH}_{4}-\mathrm{N}\right)$}

The $\mathrm{NH}_{4}-\mathrm{N}$ variations in the leachate are shown in Fig. $(\mathbf{4 a}, \mathbf{b})$. Not considering the temperature adjustment phase, the $\mathrm{NH}_{4}-\mathrm{N}$ concentrations decreased from $1100-1500 \mathrm{mgL}^{-1}$ to less than $200 \mathrm{mgL}^{-1}$. When $\mathrm{L} / \mathrm{S}=4.3$, the psychrophilic LSR's leachate $\mathrm{NH}_{4}-\mathrm{N}$ concentration decreased to $181 \mathrm{mgL}^{-1}$, which was $85 \%$ of the mesophilic $\left(213 \mathrm{mgL}^{-1}\right)$ and $65 \%$ of the thermophilic (278 $\left.\mathrm{mgL}^{-1}\right)$, respectively (Fig. $4 \mathbf{b}$, lowest curve). Higher temperatures obviously stimulated the $\mathrm{NH}_{4}-\mathrm{N}$ release from the organic matter, which resulted in higher leachate $\mathrm{NH}_{4}$ $\mathrm{N}$ concentrations in the thermophilic and mesophilic LSRs; but they are still much higher than the discharge limit value both in the low and high temperature LSRs. The temperature impact on $\mathrm{NH}_{4}-\mathrm{N}$ leaching was more obvious at a low $\mathrm{L} / \mathrm{S}$ ratio; with the increase of $\mathrm{L} / \mathrm{S}$ ratio, this phenomenon was weakened but still stronger than the impact on COD. As with COD, the decrease of the concentrations is relatively slow with the high $\mathrm{L} / \mathrm{S}$ ratio, which indicates a long aftercare period. Comparison of nitrogen concentrations close to $\mathrm{L} / \mathrm{S}=4$ showed similar relative values at different temperatures as with COD. The concentration of $\mathrm{NH}_{4}-\mathrm{N}$ showed a slower decline and a longterm consistent tendency in leachate. This suggests that $\mathrm{NH}_{4}-\mathrm{N}$ will be of most concern in the long run and more attention should be paid to the effective removal of $\mathrm{NH}_{4}-\mathrm{N}$ from leachate.

\section{LFG and Waste Degradation}

The cumulative gas production at different temperatures is shown in Fig. (5a). When the $\mathrm{L} / \mathrm{S}$ ratio was 1.3 , the thermophilic LSRs generated $52 \%$ more gas than the psychrophilic and $11 \%$ more than the mesophilic and remained until the $\mathrm{L} / \mathrm{S}=2.8$. When $\mathrm{L} / \mathrm{S}=4.15$, these values decreased to $47 \%$ and $9 \%$. A higher operational temperature accelerates the gas generation, and the impact shows a rather stable tendency over a long period (Fig. 5c). The landfill gas emission in thermophilic conditions was $110 \mathrm{Lkg}^{-1}$ waste (dry), compared to $100 \mathrm{Lkg}^{-1}$ waste (dry) in the mesophilic LSR and $75 \mathrm{Lkg}^{-1}$ waste (dry) in the psychrophilic LSR. The LFG generation rate at different temperatures is illustrated in Fig. (5b). The difference caused by the temperatures mostly occurred with an L/S ratio lower than 0.9. The thermophilic LSR showed the highest gas generation rate, the mesophilic LSR showed a slightly lower rate, and the psychrophilic LSR 

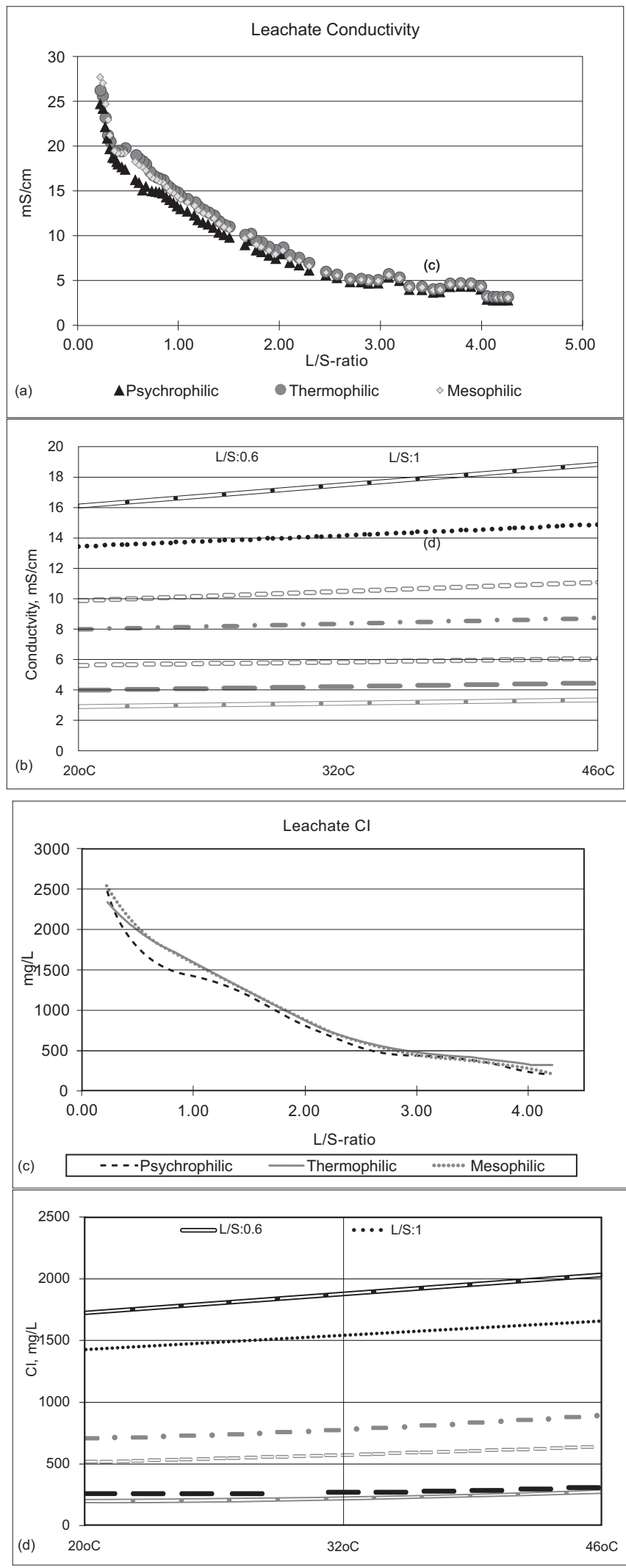

Fig. (2). Temperature impacts on conductivity and chlorides with different liquid to solid (L/S) ratios (and time) (panels a and c) and same concentrations with fixed L/S ratios (0.6 to 4.3 , see legends) as a function of temperature (panels $\mathbf{b}$ and $\mathbf{d}$ ).
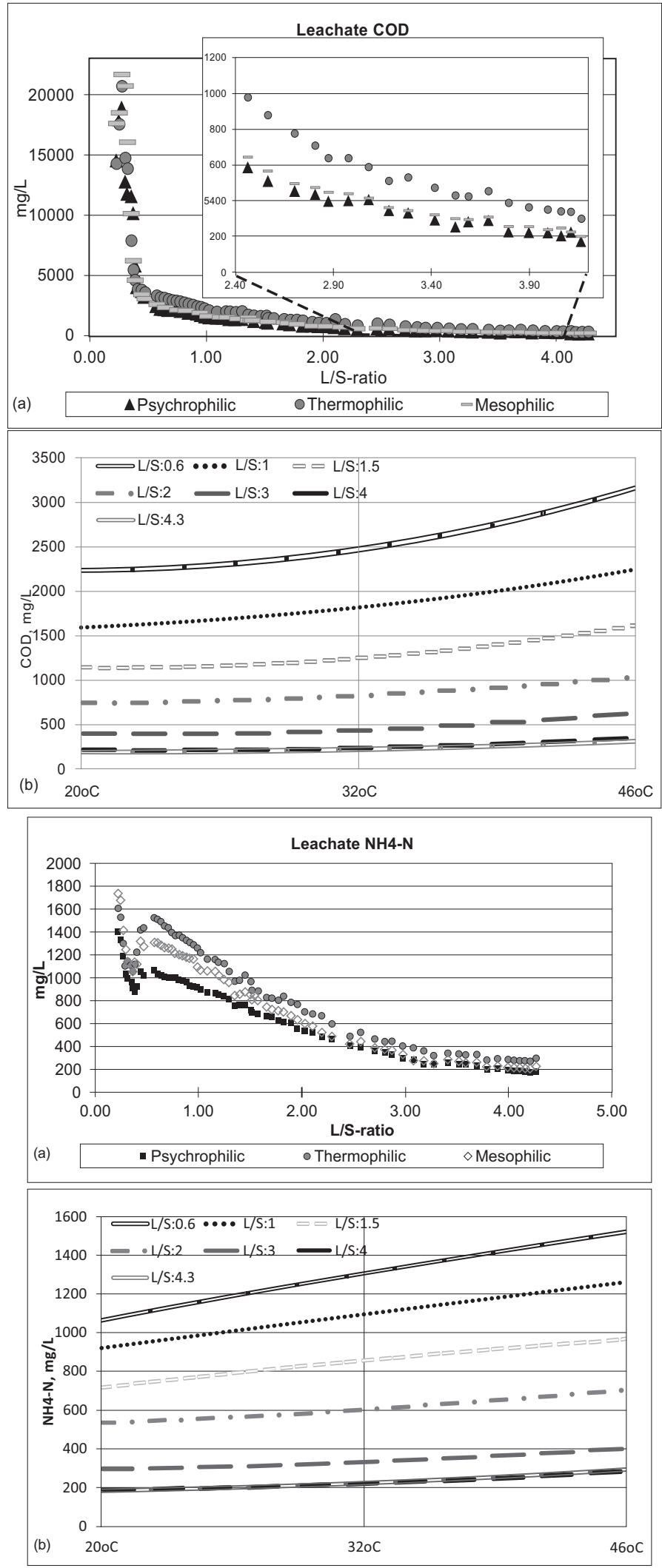

Fig. (4). Temperature impact on $\mathrm{NH}_{4}-\mathrm{N}$ with the development of liquid to solid (L/S) ratio (andtime) (a) and $\mathrm{NH}_{4}-\mathrm{N}$ concentrations with fixed L/S ratios ( 0.6 to 4.3 , see legends) as a function of temperature (b). 
showed only half the rate. This indicates that a higher temperature accelerated the rates of gas production. This phenomenon faded after the $\mathrm{L} / \mathrm{S}$ ratio was over 1.53 (Fig. 5d). When $\mathrm{L} / \mathrm{S}=4.15$, the $\mathrm{LFG}$ generation rates at the different temperatures were almost the same: psychrophilic, $5.4 \mathrm{Lkg}^{-1}$ waste (dry)year ${ }^{-1}$; mesophilic, $4.9 \mathrm{Lkg}^{-1}$ waste (dry)year ${ }^{-1}$; and thermophilic, $5.5 \mathrm{~L}^{-1} \mathrm{~kg}$ waste (dry)year ${ }^{-1}$. All of them are higher than the target value for aftercare, but the mesophilic condition shows the most positive potential compared to the thermophilic and psychrophilic. Moreover, the residual VS compositions after an $\mathrm{L} / \mathrm{S}$ ratio higher than 4.35 were $25 \%$ in psychrophilic, $28 \%$ in mesophilic, and $26 \%$ in thermophilic conditions. These values indicate rather small differences among the simulators. With this L/S ratio, the stable $\mathrm{CH}_{4}$ composition of the mesophilic LFG was around $56 \%$, which was higher than the thermophilic one $(51 \%)$ and lower than the psychrophilic one $(58 \%)$ The generated methane volumes were $187 \mathrm{~L} \mathrm{CH}_{4} \mathrm{~kg}^{-1} \mathrm{VS}$ in psychrophilic LSR, $289 \mathrm{~L} \mathrm{CH}_{4} \mathrm{~kg}^{-1}$ VS in mesophilic LSR, and $288 \mathrm{~L} \mathrm{CH}_{4} \mathrm{~kg}^{-1} \mathrm{VS}$ in the thermophilic one.

The cumulative gas production and methane generation can be used as an indicator of the waste degradation degree. When the gas generation was $75 \mathrm{~L} \mathrm{gaskg}^{-1}$ waste (dry) in psychrophilic conditions (final $\mathrm{L} / \mathrm{S}=4.35$ ), the leachate $\mathrm{NH}_{4}-\mathrm{N}$ and COD concentration was only $13 \%$ and $7 \%$, respectively, of that in thermophilic conditions. However, synchronously, the completely leached $\mathrm{NH}_{4}-\mathrm{N}$ and COD in psychrophilic conditions was $247 \%$ and $130 \%$ of those in thermophilic conditions at this degree of degradation. This correspondingly implies a higher effect on leachate treatment during the stabilisation. However, cumulative gas production cannot be considered as the only measure of stabilisation. In general, higher temperatures stimulated the waste degradation and methane generation, which is meaningful for the LFG utilisation. The psychrophilic condition results in lower LFG emission and $\mathrm{CH}_{4}$ generation, but it seems that it would not extend the waste stabilisation period compared to the thermophilic condition.

As a whole, temperature increase to thermophilic range showed similar features as in anaerobic digesters, such as increased gas production and NH4-N concentration [24] and clearly higher soluble COD concentrations [25]. However, related to landfills these features have quite different and long-term implications.

\section{Emission Balances}

Comparison of cumulative emissions through water path and gas path is given in Table 2. In the Table, TOC emissions are calculated based mainly on COD data and an average COD/TOC- ratio of 2.55. At the lowest temperature the fraction of carbon removed through water path has been the highest, which is related to the lower biological activity (gas production). Hence water removal (exchange) from the reactor has stronger impact on the carbon removal at low temperature than in the mesophilic range. Interestingly in thermophilic range carbon removed through water path has been slightly higher than in the mesophilic range, which is due to clearly elevated concentrations of TOC, COD and $\mathrm{NH}_{4}-\mathrm{N}$ in liquid phase in the thermophilic range. When the liquid phase emissions from the first 1000-day test period
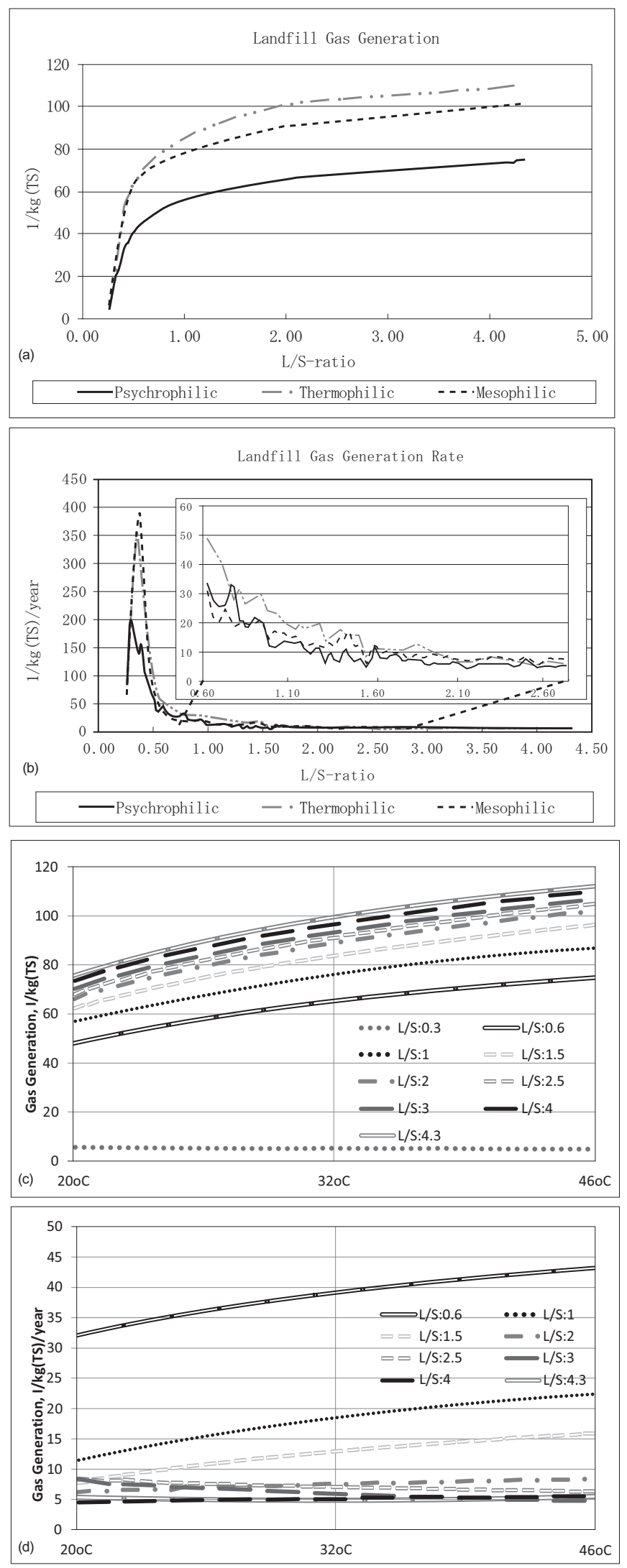

Fig. (5). Temperature impact on LFG with different liquid to solid (L/S) ratios (and time) (a: cumulative gas generation; b: gas generation rate) and the same with fixed L/S ratios (0.6 to 4.3, see legends) as a function of temperature (c and $\mathbf{d}$ ). 
[18] are compared with the whole test period, it seems that the cumulative emissions shown in Table 2 are in maximum $10 \%$ higher. However the total amount of water added has been $40 \%$ higher ( $\mathrm{L} / \mathrm{S}$ ratio in Table 2 ), which indicates the importance of dilution at higher L/S ratios. Accordingly, to avoid further extensive dilution in-situ management alternatives are an interesting option. Total emissions are higher than shown in [15] with mesophilic simulators containing lower fraction of organic matter than in this study, which explains much of the difference.

Table 2. Cumulative Emissions at Different Temperatures with Liquid to Solid (L/S) Ratio 4.3

\begin{tabular}{|l|c|c|c|c|}
\hline Temperatures, ${ }^{\mathbf{0}} \mathbf{C}$ & $\mathbf{2 0}$ & $\mathbf{3 3}$ & $\mathbf{4 6}$ & \\
\hline \hline Liquid path \\
\hline TOC & 3.88 & 4.04 & 4.45 & $\mathrm{gkg}^{-1} \mathrm{TS}$ \\
\hline $\mathrm{COD}$ & 10.0 & 10.4 & 11.4 & $\mathrm{gkg}^{-1} \mathrm{TS}$ \\
\hline $\mathrm{NH}_{4}-\mathrm{N}$ & 2.59 & 3.01 & 3.34 & $\mathrm{gkg}^{-1} \mathrm{TS}$ \\
\hline Gas path & & \\
\hline Carbon & 33.0 & 45.1 & 47.6 & $\mathrm{gkg}^{-1} \mathrm{TS}$ \\
\hline Carbon total & 36.9 & 49.2 & 52.0 & $\mathrm{gkg}^{-1} \mathrm{TS}$ \\
\hline Carbon in liquid phase & 10.5 & 8.2 & 8.6 & $\%$ \\
\hline
\end{tabular}

\section{Post-Closure Management and Temperature Impact Coefficients}

The impacts of temperature emerged in all the parameters mentioned. The thermophilic reactors showed the highest cumulative gas production, gas generation rate, leachate $\mathrm{COD}$ and $\mathrm{NH}_{4}-\mathrm{N}$ concentrations, whereas the psychrophilic reactors resulted in the lowest levels. It is clear that before the landfill closure (e.g., 30 years), all the parameters of the leachate under all the temperatures mentioned are still much higher than the target values, but the thermophilic reactors had the highest overall degree of degradation $(6 \%$ higher than mesophilic reactors and 55\% higher than psychrophilic). With the same waste degradation degree (75 $\mathrm{L}_{\text {gaskg }^{-1}}$ waste (dry)), the cumulative leachate treatment costs (in WWTP) under psychrophilic conditions were estimated to be 1.9 times those under mesophilic conditions and 2.1 times those under thermophilic conditions [26]. The decreasing rates of COD and $\mathrm{NH}_{4}-\mathrm{N}$ concentrations were also temperature-dependent, which means that the decrease of leachate concentration was faster under higher temperatures; however, this impact will decrease when a high $\mathrm{L} / \mathrm{S}$ ratio is achieved. Hence, the increase in temperature can accelerate waste degradation and gas generation, but cannot decrease the length of the waste stabilisation since it will extend the waste degradation degree. To considerably decrease the stabilisation period, a higher annual L/S ratio rate was verified to be an effective factor [18].

The temperature coefficients for different parameters as a function of the $\mathrm{L} / \mathrm{S}$ ratio were estimated in Table 3. The results indicate that the temperature increase showed a rather similar impact on conductivity, chloride, and $\mathrm{NH}_{4}-\mathrm{N}$. It means that the emissions increased synchronously with the increase in temperature, and the rate of increase was approximately the same in psychrophilic, mesophilic, and thermophilic conditions. For the COD emission, as the temperature changed from mesophilic to thermophilic, the value of the $\mathrm{COD}$ increased by $1.5 \%{ }^{\circ} \mathrm{C}^{-1}$, which was $67 \%$ higher than when the temperature changed from psychrophilic to mesophilic. This confirms that a high temperature is advantageous for waste stabilisation and organics leaching. Between psychrophilic and mesophilic conditions, the impact of $1{ }^{\circ} \mathrm{C}$ increase caused a $2.8 \%$ increase in the LFG emission, which was $75 \%$ higher than the impact caused by the change from mesophilic to thermophilic conditions. Moreover, the temperature coefficients of the methane generation rate were close to each other. It verifies that a higher temperature leads to greater and faster LFG emission. However, from an efficiency point of view, the mesophilic condition is the optimum. The LFG indicates most clearly the biological activity and is thus more sensitive to temperature change than other parameters $\left(\mathrm{Cl}, \mathrm{NH}_{4}-\mathrm{N}, \mathrm{COD}\right)$, which have a stronger relation to physico-chemical phenomena such as washing.

The temperature impact on microbial growth rate in anaerobic digestion is usually in the range of $5-7 \%{ }^{\circ} \mathrm{C}^{-1}$ calculated based on general reaction rate and design data given in Henze et al. [28] and Metcalf \& Eddy [27] and is close to values estimated in [29]. In a more detailed study Siegrist et al. [29] have shown that from the biodegradation steps hydrolysis has a lower temperature sensitivity than the methanogenic step and is around $2-3 \%{ }^{\circ} \mathrm{C}^{-1}$. Among the landfill simulation studies the impact of temperature has been addressed experimentally in only a few cases. In the work of Reichel et al. [21] an equation has been used, which indicates clearly over $10 \%$ increase per $1{ }^{\circ} \mathrm{C}$ in the range 20 $35{ }^{\circ} \mathrm{C}$. However this value is connected to one simulator reactor containing old waste (with which hydrolysis should have a dominating role) and subjected to a single step temperature increase. The experiment does not reflect a longterm adaptation to temperatures near $20{ }^{\circ} \mathrm{C}$ (or in thermophilic range). In the present study such adaptation has occurred and, moreover, when leachate BOD fell below 20 $\mathrm{mgL}^{-1}(\mathrm{~L} / \mathrm{S} \leq 1)$ indicating very low VFA concentrations, hydrolysis was the rate limiting step, as can be seen in [30]. Consequently a temperature coefficient related to the hydrolysis can be expected and the findings of this study are close to the value given in [29]. Moreover, landfill simulator results extend experimental data to the lower thermophilic range.

The temperature ranges in this study cover rather well the temperature ranges found in field conditions shown earlier and recently in [31]. As a result, when estimating long-term methane emissions from landfills, one must be cautious and select temperature coefficients carefully, based on representative data. Otherwise misleading emission development may result, which will affect landfill management options in long-term and life cycle inventories.

From the LFG generation and utilisation point of view, a higher temperature is beneficial to increase methane utilisation efficiency. For small and medium-size landfills, attempts to maintain optimal temperatures for landfill operations are required. A bottom water insulating layer or 
Table 3. Temperature Impact Coefficients

\begin{tabular}{|c|c|c|c|c|c|}
\hline \multirow{2}{*}{ L/S Ratio } & \multicolumn{5}{|c|}{ Estimated Temperature Coefficient, $\boldsymbol{\theta}: \mathrm{C}_{\mathrm{T}}=\mathrm{C}_{\mathrm{t}} \times \boldsymbol{\theta}^{(\mathrm{T}-\mathrm{t})} *$} \\
\hline & $\begin{array}{c}\text { Conductivity } \\
\text { mSem }^{-1}\end{array}$ & Chloride, $\operatorname{mgL}^{-1}$ & $\mathrm{NH}_{4}-\mathrm{N}, \mathrm{mgL}^{-1}$ & COD, $\mathrm{mgL}^{-1}$ & LFG, Lkg $^{-1}$ TS \\
\hline \multirow{2}{*}{0.6} & \multirow{2}{*}{1.007} & $1.016\left(20-32^{\circ} \mathrm{C}\right)$ & $1.017\left(20-32^{\circ} \mathrm{C}\right)$ & $1.008\left(20-32^{\circ} \mathrm{C}\right)$ & $1.034\left(20-32^{\circ} \mathrm{C}\right)$ \\
\hline & & $1.006\left(32-46^{\circ} \mathrm{C}\right)$ & $1.014\left(32-46^{\circ} \mathrm{C}\right)$ & $1.013\left(32-46^{\circ} \mathrm{C}\right)$ & $1.017\left(32-46^{\circ} \mathrm{C}\right)$ \\
\hline \multirow{2}{*}{1} & \multirow{2}{*}{1.004} & $1.014\left(20-32^{\circ} \mathrm{C}\right)$ & $1.014\left(20-32^{\circ} \mathrm{C}\right)$ & $1.011\left(20-32^{\circ} \mathrm{C}\right)$ & $1.028\left(20-32^{\circ} \mathrm{C}\right)$ \\
\hline & & $1.006\left(32-46^{\circ} \mathrm{C}\right)$ & $1.012\left(32-46^{\circ} \mathrm{C}\right)$ & $1.013\left(32-46^{\circ} \mathrm{C}\right)$ & $1.016\left(32-46^{\circ} \mathrm{C}\right)$ \\
\hline \multirow{2}{*}{1.5} & \multirow{2}{*}{1.005} & $1.013\left(20-32^{\circ} \mathrm{C}\right)$ & $1.015\left(20-32^{\circ} \mathrm{C}\right)$ & $1.007\left(20-32^{\circ} \mathrm{C}\right)$ & $1.028\left(20-32^{\circ} \mathrm{C}\right)$ \\
\hline & & $1.006\left(32-46^{\circ} \mathrm{C}\right)$ & $1.012\left(32-46^{\circ} \mathrm{C}\right)$ & $1.013\left(32-46^{\circ} \mathrm{C}\right)$ & $1.017\left(32-46^{\circ} \mathrm{C}\right)$ \\
\hline \multirow{2}{*}{2} & \multirow{2}{*}{1.004} & $1.009\left(20-32^{\circ} \mathrm{C}\right)$ & $1.009\left(20-32^{\circ} \mathrm{C}\right)$ & $1.009\left(20-32^{\circ} \mathrm{C}\right)$ & $1.027\left(20-32^{\circ} \mathrm{C}\right)$ \\
\hline & & $1.009\left(32-46^{\circ} \mathrm{C}\right)$ & $1.010\left(32-46^{\circ} \mathrm{C}\right)$ & $1.013\left(32-46^{\circ} \mathrm{C}\right)$ & $1.017\left(32-46^{\circ} \mathrm{C}\right)$ \\
\hline \multirow{2}{*}{2.5} & \multirow{2}{*}{1.003} & $1.011\left(20-32^{\circ} \mathrm{C}\right)$ & $1.005\left(20-32^{\circ} \mathrm{C}\right)$ & $1.008\left(20-32^{\circ} \mathrm{C}\right)$ & $1.027\left(20-32^{\circ} \mathrm{C}\right)$ \\
\hline & & $1.008\left(32-46^{\circ} \mathrm{C}\right)$ & $1.008\left(32-46^{\circ} \mathrm{C}\right)$ & $1.013\left(32-46^{\circ} \mathrm{C}\right)$ & $1.016\left(32-46^{\circ} \mathrm{C}\right)$ \\
\hline \multirow{2}{*}{4} & \multirow{2}{*}{1.004} & $1.003\left(20-32^{\circ} \mathrm{C}\right)$ & $1.011\left(20-32^{\circ} \mathrm{C}\right)$ & $1.008\left(20-32^{\circ} \mathrm{C}\right)$ & $1.026\left(20-32^{\circ} \mathrm{C}\right)$ \\
\hline & & $1.007\left(32-46^{\circ} \mathrm{C}\right)$ & $1.016\left(32-46^{\circ} \mathrm{C}\right)$ & $1.019\left(32-46^{\circ} \mathrm{C}\right)$ & $1.016\left(32-46^{\circ} \mathrm{C}\right)$ \\
\hline \multirow{2}{*}{4.2} & \multirow{2}{*}{1.005} & $1.008\left(20-32^{\circ} \mathrm{C}\right)$ & $1.015\left(20-32^{\circ} \mathrm{C}\right)$ & $1.010\left(20-32^{\circ} \mathrm{C}\right)$ & $1.025\left(20-32^{\circ} \mathrm{C}\right)$ \\
\hline & & $1.013\left(32-46^{\circ} \mathrm{C}\right)$ & $1.018\left(32-46^{\circ} \mathrm{C}\right)$ & $1.019\left(32-46^{\circ} \mathrm{C}\right)$ & $1.015\left(32-46^{\circ} \mathrm{C}\right)$ \\
\hline \multirow{2}{*}{ Average } & \multirow{2}{*}{1.005} & $1.011\left(20-32^{\circ} \mathrm{C}\right)$ & $1.012\left(20-32^{\circ} \mathrm{C}\right)$ & $1.009\left(20-32^{\circ} \mathrm{C}\right)$ & $1.028\left(20-32^{\circ} \mathrm{C}\right)$ \\
\hline & & $1.008\left(32-46^{\circ} \mathrm{C}\right)$ & $1.013\left(32-46^{\circ} \mathrm{C}\right)$ & $1.015\left(32-46^{\circ} \mathrm{C}\right)$ & $1.016\left(32-46^{\circ} \mathrm{C}\right)$ \\
\hline
\end{tabular}

*where,

T: target temperature $\left({ }^{\circ} \mathrm{C}\right)$

$\mathrm{C}_{\mathrm{T}}$ : concentration (or volume) at target temperature.

t: reference temperature $\left({ }^{\circ} \mathrm{C}\right)$.

$\mathrm{C}_{\mathrm{t}}$ : concentration (or volume) at reference temperature (equation according to [27]; the exponential equation indicates in practice the same percentage change per degree ${ }^{\circ} \mathrm{C}$ as the Arrhenius type of equation)

recirculated leachate heating could be considered [7, 32]. However, if the LFG collection and energy recovery were not required, a landfill temperature increase is not intended because there is no significant environmental benefit when considering a long aftercare period.

When considering the post-closure management needs, under psychrophilic condition, the residual COD concentrations after around 200 years (in field conditions mentioned before) were close to the direct discharge limit, which is $200 \mathrm{mgL}^{-1}$. Under thermophilic and mesophilic conditions, the residual COD concentration is still clearly higher than the limit. In the case of nitrogen, the same trend can be seen, but the target value is still far below the level achieved in this study, indicating the dominating status of nitrogen for the length of the aftercare period. Specific in situ leachate management and pre-treatment processes (e.g., nitrification-denitrification plus post-denitrification system) are compulsory for countries with leachate indirect discharge limits, which are also profitable from the cost control point of view [26]. The estimation of the length of the aftercare period is based on the target values, and landfill aftercare only ends when the parameters shows no adverse effects on the environment according to the target values. This study indicates that the aftercare period may exceed 200 years until the leachate meets the mentioned target values. This period can be shortened to some extent with a suitable leachate management and treatment system, including water recirculation to achieve faster the target $\mathrm{L} / \mathrm{S}$ ratio. To optimize aftercare from the cost point of view, different landfill management scenarios and leachate treatment alternatives have to be evaluated related to circumstances in question, which is an extensive topic. Therefore these issues has been targeted by the authors in a separate paper [33]. As a whole the results give new information to evaluate applicable long-term strategies in various environmental conditions and for modeling. The long duration of the required aftercare period in anaerobic conditions indicates that other alternatives like changing conditions at a suitable $\mathrm{L} / \mathrm{S}$ ratio to a faster aerobic degradation may also be useful, as shown in [15].

\section{CONCLUSION}

This long-term anaerobic landfill simulation achieved a liquid to solid (L/S) ratio of 4.35 , which corresponds to over 190 years in a typical big landfill excluding water recirculation, without achieving leachate limit values for nitrogen. This shows that a 30 - to 40 -year aftercare period is insufficient and other alternatives are needed to shorten the aftercare period. Total emissions of organics and nitrogen will increase further only slightly with the L/S-ratio in longterm.

Thermophilic conditions resulted due to faster degradation in greater gas generation $(+47 \%)$ and higher leachate $\mathrm{COD}$ and $\mathrm{NH}_{4}-\mathrm{N}$ concentrations (around $+60 \%$ ) compared with psychrophilic ones; in mesophilic conditions they were $+33 \%$ for gas generation and around $+15 \%$ for $\mathrm{COD}$ and $\mathrm{NH}_{4}-\mathrm{N}$. Hence thermophilic conditions will prolong the aftercare period, whereas psychrophilic conditions will require a shorter aftercare period, based on decreasing rates of leachate concentrations. Mesophilic 
conditions compromise near thermophilic gas production and near psychrophilic leachate concentrations.

The highest sensitivity to temperature was related to gas generation $\left(1.6-2.8 \%{ }^{\circ} \mathrm{C}^{-1}\right)$, connected to the biological activity. This result differs considerably from the scarce experimental studies of landfill simulations related to temperature, but is consistent with hydrolysis (solubilisation) related phenomena as a rate limiting step. Leached $\mathrm{COD}, \mathrm{NH}_{4}-\mathrm{N}$ and chloride concentrations had similar but not as high temperature sensitivity.

The results give new information for the estimation of longterm emissions in different environmental conditions and management alternatives and for modelling. A further question concerns how to achieve an acceptable target value for a specific landfill situation.

\section{ACKNOWLEDGEMENT}

Part of this study was carried out at the Laboratory of Environmental Engineering, Helsinki University of Technology. We are very grateful to our colleagues for their support.

\section{CONFLICT OF INTEREST}

None declared.

\section{REFERENCES}

[1] S. T. S. Yuen, "Bioreactor landfills: Do they work?", in Geoenvironment 2001: 2nd ANZ Conference on Environmental Geotechnics, Newcastle, Australia, pp. 28-30 November 2001.

[2] M. Warith, "Bioreactor landfills: experimental and field results", Waste Manage., vol. 22, pp. 7-17, 2002.

[3] T. H. Christensen, R. Cossu, R. Stegmann, "Landfilling of Waste: leachate", Elsevier Applied Science, 1992.

[4] M. El-Fadel, A. Findikakis, J. Leckie, "Environmental impacts of solid waste landfilling", J. Environ.. Manage., vol. 50, pp. 1-25, 1997.

[5] J. Ejlertsson, A. Karlsson, A. Lagerkvist, "Effects of co-disposal of wastes containing organic pollutants with municipal solid waste - a landfill simulation reactor study", Adv. Environ. Res., vol. 7, pp. 949960, 2003.

[6] V. A. Vavilin, S. Jonsson, J. Ejlertsson, "Modelling MSW decomposition under landfill conditions considering hydrolytic and methanogenic inhibition", Biodegradation, vol. 17, pp. 389-402, 2006.

[7] K. E. Hartz, R. E. Klink, and R. K. Ham, "Temperature effects: methane generation from landfill samples", J. Environ. Eng. Div., Proceedings of the American Society of Civil Engineers, vol. 108, pp. 629-638, 1982.

[8] J. F. Rees, "Optimization of methane production and refuse decomposition in landfills by temperature control", J. Chem. Tech. Biotechnol., vol. 30, pp. 458-465, 1980 .

[9] J. Mata-Alvares, A. Martina-Verdure, "Laboratory simulation of municipal solid waste fermentation with leachate recycle", J. Chem. Tech. Biotech., vol. 36, pp. 547-556, 1986.

[10] N. C. Blakey, K. Bradshaw, P. Reynolds, "Bioreactor landfill - a field trial of accelerated waste stabilization", in 6th International Waste Management and Landfill Symposium Proceedings, pp. 375-386, 1997.

[11] H. Robinson, "The Composition of Leachates From Very Large Landfills: An International Review", CWRM, vol. 8, no. 1, pp. 19-32, 2007.

[12] EU, Council Directive 1999/31/EC on the landfill of Waste. Official J. Eur. Commun., 1999.
[13] R. Stegmann, K-U. Heyer, K. Hupe, M. Ritzkowski, "Discussion of criteria for completion of landfill aftercare", In 9th International Waste Management and Landfill Symposium Proceedings, 2003.

[14] K-U. Heyer, K. Hupe, R. Stegmann, "Landfill aftercare --- scope for actions, duration, costs and quantitative criteria for the completion", in 7th International Waste Management and Landfill Symposium Proceedings, 2005.

[15] K-U. Heyer, Emissionsreduzierung in der Deponienachsorge. Hamburger Berichte 21, Abfallwirtschaft, Technische Universität Hamburg- Harburg, 2003.

[16] D. T. Sponza, O. N. Ağdağ, "Impact of leachate recirculation and recirculation volume on stabilization of municipal solid wastes in simulated anaerobic bioreactors", Proc. Biochem., vol. 39, pp. $2157-$ 2165,2004

[17] A. Giannis, G. Makripodis, F. Simantiraki, "Monitoring operational and leachate characteristics of an aerobic simulated landfill bioreactor", Waste Manage., vol. 28, pp. 1346-1354, 2008.

[18] G. D. Gioannis, A. Muntoni, G. Cappai, "Landfill gas generation after mechanical treatment of municipal solid waste, estimation of gas generation rate constants", Waste Manage., vol. 29, pp. 1026-1034, 2009.

[19] Y. Wang, M. Pelkonen, "Impacts of temperature and liquid/solid ratio on anaerobic degradation of municipal solid waste: an emission investigation of landfill simulation reactors", J. Mat. Cycles Waste Manage., vol. 11, pp. 312-320, 2009.

[20] J. White, J. Robinson, Q. Ren, "Modelling the biochemical degradation of solid waste in landfills", Waste Manage., vol. 24, pp. 227-240, 2004.

[21] T. Reichel, L. Ivanova, R. Beaven, A. Haarstrick, "Modeling decomposition of MSW in a consolidating anaerobic reactor", Environ. Eng. Sci., vol. 24, pp. 1072- 1083, 2007.

[22] N. Gawande, D. Reinhart, G. Yeh, "Modelling microbiological and chemical processes in municipal solid waste reactor, part II: application of numerical model BIOKEMOD-3P”, Waste Manage., vol. 30, pp. 211-218, 2010.

[23] R. Valencia, "Enhanced stabilization of municipal solid waste in bioreactor landfills", Dissertation Wageningen University, CRC Press/Balkema, Leiden, Netherlands, 2008.

[24] D. Bolzonella, C. Cavinato, F. Fatone, P. Pavan, F. Cecchi, "High rate, mesophilic, thermophilic and temperature phased anaerobic digestion of waste activated sludge: A pilot scale study", Waste Manage., (in press), 2012.

[25] Y-C. Song, S-J Kwon, J-H Woo, "Mesophilic and thermophilic temperature co-phase anaerobic digestion compared with single-stage mesophilic and thermophilic digestion of sewage sludge", Water Res., vol. 38, pp. 1653-1662, 2004.

[26] Y. Wang, M. Pelkonen, J. Kaila, "Cost-saving biological nitrogen removal from strong ammoniac landfill leachate", Waste Manag. Res., vol. 29, pp. 797-806, 2011.

[27] Metcalf \& Eddy, Wastewater engineering, treatment and reuse. 4th ed. McGraw-Hill, New York, 2003.

[28] M. Henze, P. Harremoes, J. la Cour Jansen, E. Arvin, Wastewater Treatment. Biological and Chemical Processes. Springer Verlag Berlin, 2002

[29] H. Siegrist, D. Vogt, J. Garcia-Heras, W. Gujer, "Mathematical model for meso- and thermophilic anaerobic sewage sludge digestion", Environ. Sci. Technol., vol. 36, no. 5, pp. 1113-23, 2002.

[30] V. Vavilin, S. Rytov, L. Lokshina, S. Pavlostathis, M. Barlaz, "Distributed model of solid waste anaerobic digestion. Effects of leachate recirculation and $\mathrm{pH}$ adjustment", Biotech. Bioeng., vol. 81, no. 1, pp. 67-73, 2003.

[31] J. Hanson, N. Yesiller, N. Oettle, "Spatial and temporal temperature distributions in municipal solid waste landfills", J. Environ. Eng., vol. 136(8), pp. 804-814, 2010.

[32] M. Warith, X. Li, H. Jin, "Bioreactor landfills: state-of-the-art review", Emirates J. Eng.. Res., vol. 10, no. 1, pp. 1-14, 2005.

[33] Y. Wang, M. Pelkonen, J. Kaila, "Optimization of landfill leachate management in the aftercare period", Waste Manage. Res., (in press), 2012. 